\title{
"NEWFOUNDLAND ON"
}

THROUGHOUT the winter, Dick Bird, Canada's foremost nature photographer from Regina, has been lecturing in various cities of the States on the natural hife and beauty of our newest province, Newfoundland.

An Audubon Wildlife Program presented by the Detroit Audubon Society, was sent to us by H. L. Paine of Moose Jaw. In it there is an outline of $\mathrm{Mr}$. Bird's lecture there on January 17, which gives one a good idea of the scope of his illustrated talk, called "Newfoundland On."

"Introduction to Canada's newest province, the land of John Cabot, the island of the caribou, its flora and fauna. Rugged coastlines of eastern Canada, sea bird islands, Kittiwakes, Murres, Puffins, caribou, moose, bear and smaller mammals. Exciting pictures of salmon fishing, whaling and trout fishing, Canadian industries, handicrafts, and its natural resources, the great forest, immense marshlarids with typical wildlife, its network of lakes and rivers and the rugged coast of Labrador with its interesting bird life."

Because of his assistance to and continued support of our efforts over a period of years, and in view of his outstanding contributions in the field of nature photography, Dick Bird was made an honorary life member of the Saskatchewan Natural History Society twc years ago.

\section{Nature Notes from Spruce Dale Farm}

C. Stuart Francis, Torch River

SPRING came with a rush this year,

with abnormal high temperatures and resultant very early plant growth. We expected this might be followed by later severe frosts and cold weather which might have done severe damage to new young growth and fruit and flower bloom. However, the expected cold snap has not materialized, in this area at least, and native plants are all away to a good start with Buffalo-berry bloom on April 30; Mertensia, or wild Bluebell, on May 15. Honeysuckle had grown up to 9 inches of new growth. with flower buds on May 15, and Manitoba Maples were loaded with a new seed crop on the same day. Native White Spruce had grown as much as 3 to 4 inches by May 24; Saskatoons and Pincherry had already a well-tormed fruit set by May 24 also, and on Victoria Day the spring northward migration of nearly all the birds had been completed, except for a very few species, such as the Hummingbird and Nighthawk, which have not been seen here as yet.

The trees around our buildings now look beautiful in their new growth and the well established species, either growing naturally or planted are as follows: White Spruce, Black Spruce, Jackpine, Scotch Pine, Lodgepole Pine, Balsam Fir, Tamarack,
Manitoba Maple, Green Ash, Bur Oak, Aspen Poplar, Balsam Poplar, Laurel Willow, Red Elder, Ginnalian Maple, Siberian Crabapple and $\mathrm{Na}-$ tive Plum.

This spring we have planted the following species of trees, some in considerable numbers, and others, only single specimens; Red Pine, Norway Spruce, European Larch, Siberian Larch, White Cedar, Manchurian Elm, Manchurian Pear, White Ash, American Elm, Basswood, Butternut and Mountain Ash.

Some of the Red Pine we planted has needles over six inches long, and we are hoping they will be able to stand out severe north-western climate. They surely must look beautiful when they have reached a size of ten or fifteen feet.

All along the creeks the Beaver have repaired their dams, after the damage caused them by the rapid spring run-off, and are busy building new dams everywhere. And so, more small lakes and ponds are created, where more wild ducks and other waterfowl can find more nesting sites in which to raise their broods. I can stand on a beaver dam on my own land and count as many as five different species at one time. which are spending the summer at this particular farm. They are: Green-winged (Continued on Page 14) 


\section{"People of the Deer"}

\section{by Farley Mowat. McLelland \& Stewart. 1952}

(Reviewed by Dr. Stuart Houston)

THIS is without a doubt one of the most interesting books that this reviewer has ever read. It is a superb adventure stcry, very well written. But it is much more than this. It is the story of the Caribou and of the little-known and now vanishing tribe of Eskimos who depended on the vast herds of caribou for their livelihood. It portrays the tragic results of the white man's greed, and the calamitous effects of his neglect for the basic principles of conservation. The book is of special ethnological interest, too, because it portrays the life and habits of a tribe of Eskimos who have probably had less contact with the white man than any other native group on this continent. Finally, the book is of interest because the territory it covers includes the far northeastern corner of Saskatchewan, and because its author is a naturalist and former "Blue Jay" contributor, who was raised in Saskatoon.

Farley Mowat was born in 1921 at Belleville, Ont., but the family later moved to Saskatoon where his father became city librarian. Farley spent most of his time, after fours and weekends, mousing about in the swamps and bluffs looking for birds. In 1939 he spent the summer with three other young naturalists studying the fauna of Saskatchewan, and his "Notes on the Birds of Emma Lake, Sask.," recording 156 species, was published in the May 1947 "Crnadian Field-Naturalist." Toward the end of 1939, he enlisted in the Army, was commissioned as a lieutenant and served in England, Sicily and Italy. He served as an Intelligence officer during the invasion of Europe. On discharge from the Army in the spring of 1946, he bought a jeep and came back to Saskatchewan to study the birds at Dundurn and Lac la Ronge. (Members will remember the article he wrote for the Sept. 1946 "Blue Jay" about his observations of that summer.) 1947 and 1948 were spent in the arctic Barren Lands, studying the Ilhamuit, the People of the Deer. He is now married and living at Palgrave, Ont.

Mowat's book is currently becoming a best-seller in the United States, and is a book that no Canadian should miss reading. It is published in Canada by McLelland and Stewart and may be obtained through any book store.

\section{Appreciation}

\section{Ronald Hooper - Somme}

$\mathbf{M}^{\mathrm{y}}$ brother and I are amateur ornithologists and taxidermists. After being advised by $\mathrm{Mr}$. Fred Bard, the Director, we recently made a trip to the Provincial Museum in Regina.

Readers are missing a great deal if they have not visited this museum. Seeing it gave us many ideas for improving our taxidermy work. We were invited into the preparation room and did some mounting, using improved methods taught to us by Fred Lahrman, Mr. Bard's taxidermist.

We were encouraged to proceed with nature photography. The 35 m.m. Retina camera was recommended. This is a "honey" of a camera which is relatively cheap in spite of its efficiency.
We greatly appreciate the willing co-operation of the museum staff in helping amateur naturalists.

\section{NATURE NOTES FROM SPRUCE DALE FARM}

\section{(Continued from Page 11)}

and Blue-winged Teal, Mallard, Golden-eye, and Baldpate.

You can see a big bear crossing from one bluff to another; a deer standing out in the open field, to get away from the flies which torment it in the thick forest growth; a Vireo or a Robin singing from the top of a sixty or seventy foot aspen tree. A few fleecy clouds may be floating across a rich blue sky, and the hum of many kinds of farm tractors can be heard in every direction-such is a spring day in Saskatchewan's North Country. 